Izabela Kamińska-Jatczak*

Elżbieta Skoczylas-Namielska*

\title{
Pedagogika społeczna w Uniwersytecie Łódzkim: przeszłość - teraźniejszość - przyszłość: kulminacja obchodów 70-lecia Katedry Pedagogiki Społecznej UŁ
}

\begin{abstract}
Abstrakt
Tekst stanowi relację z wydarzenia kończącego rok jubileuszowy Uniwersytetu Łódzkiego jak i Katedry Pedagogiki Społecznej, zatytułowanego Pedagogika społeczna w Uniwersytecie Łódzkim: przeszłość - teraźniejszość - przyszłość, które objęło dwie części: dyskusję panelową wokół problematyki zawartej w książce J.-M. Barbiera Leksykon analizy aktywności. Konceptualizacje zwyczajowych pojęć oraz wystawę poświęconą dziejom pedagogiki społecznej w UŁ. Wydarzenie było również uczczeniem setnej rocznicy urodzin profesor Ireny Lepalczyk przypadającej 1 października 2016 r.

Dyskusja dotyczyła pojęć kluczowych dla autorskiej koncepcji analizy aktywności, zaprezentowanej w Leksykonie. Podkreślano przy tym zarówno propozycję znaczeń nieoczywistych zaproponowanych przez J.-M. Barbiera, jak i oryginalną strukturę książki. Zastanawiano się również m.in. nad uniwersalnością koncepcji i samego Leksykonu.
\end{abstract}

Słowa kluczowe: aktywność, pojmowalność aktywności, analiza aktywności, rodzaje aktywności, antropologia praktyki.

\section{Social Pedagogy at the University of Lodz: Past - Present - Future: Culmination of the Celebrations of the 70th Anniversary of the Department of Social Pedagogy of the University of Lodz}

\begin{abstract}
The paper is an account of the events ending the jubilee year of the University of Lodz and the Department of Social Pedagogy, entitled Social Pedagogy at the University of Lodz: Past - Present - Future, which included two parts: a panel discussion around the
\end{abstract}

* Katedra Pedagogiki Społecznej, Wydział Nauk o Wychowaniu, Uniwersytet Łódzki. 
issues contained in the book by J.-M. Barbier Vocabulaire d'analyse des activités. Penser les conceptualisations (Lexicon of the activity analysis. Conceptualizations of customary terms) and an exhibition devoted to the history of social pedagogy at the University of Lodz. The event was also a celebration of the centenary of the birth of Professor Irena Lepalczyk occurring on 1 October 2016.

The discussion focused on key terms for the author's own concept of activity analysis, presented in the Lexicon. The emphasized elements included the proposal of unobvious meanings as well as the original structure of the book.

Keywords: activity, conceivability of activity, analysis of activity, types of activity, anthropology of practice.

W dniu 5 października 2016 r. w Pałacu A. Biedermanna - siedzibie Muzeum Uniwersytetu Łódzkiego - odbyło się wydarzenie kończące rok jubileuszowy Uniwersytetu Łódzkiego i Katedry Pedagogiki Społecznej, zatytułowane Pedagogika społeczna w Uniwersytecie Łódzkim: przeszłość - teraźniejszość - przyszłość. Objęło ono dwie części: dyskusję panelową oraz wernisaż wystawy pt. $Z$ dziejów pedagogiki społecznej na UŁ, przygotowanej przez Archiwum i Muzeum UŁ we współpracy z Katedrą Pedagogiki Społecznej UŁ. Wystawę zainaugurował słowem wstępnym dr Dariusz Klemantowicz - kierownik Archiwum i Muzeum Uniwersytetu Łódzkiego. Ekspozycja zawierała unikatowe zdjęcia, dokumenty archiwalne związane z postaciami łódzkiego środowiska pedagogów społecznych.

Wydarzenie zakończyło cykl spotkań naukowych ${ }^{1}$ związanych z obchodami jubileuszu 70-lecia Uniwersytetu Łódzkiego oraz Katedry Pedagogiki Społecznej, jednej z jego najstarszych jednostek. Stanowiło przypomnienie o rozpoczęciu przed 70 laty kształcenia pedagogów społecznych w UŁ. Dodatkowo było formą uczczenia przypadającej 1 października 2016 r. setnej rocznicy urodzin Profesor Ireny Lepalczyk.

Wzięło w nim udział 58 osób, w tym przedstawiciel władz rektorskich Uniwersytetu Łódzkiego - prof. Tomasz Cieślak, dziekan Wydziału Nauk o Wychowaniu prof. Danuta Urbaniak-Zając, która była również jednym z panelistów, oraz przedstawiciele jednostek naukowych zarówno uczelni macierzystej (Katedra Badań Edukacyjnych, Katedra Pedagogiki Społecznej, Katedra Pedagogiki Przedszkolnej i Wczesnoszkolnej, Katedra Teorii Wychowania, Instytut Psychologii, Katedra Socjologii Stosowanej i Pracy Socjalnej), jak i ośrodków naukowych w kraju

\footnotetext{
${ }^{1}$ W jego ramach w 2015 r. odbyło się: spotkanie dyskusyjne w Katedrze Pedagogiki Społecznej UŁ nt.: Pedagogika społeczna w Uniwersytecie Łódzkim: trwanie i zmiana; dyskusja nad książką Lecha Witkowskiego pt.: Niewidzialne środowisko. Pedagogika kompletna Heleny Radlińskiej jako krytyczna ekologia idei, umysłu i wychowania. O miejscu pedagogiki w przełomie dwoistości w humanistyce (2014), z udziałem Autora oraz promocja monografii wieloautorskiej, przygotowanej w ramach wydawnictw jubileuszowych na 70-lecie Uniwersytetu Łódzkiego, pt.: Pedagogika społeczna: wstępy i kontynuacje (2015), pod redakcją E. Marynowicz-Hetki, E. Skoczylas-Namielskiej.
} 
(Katedra Pedagogiki Społecznej Uniwersytetu Śląskiego, Katedra Edukacji Dorosłych Uniwersytetu Mikołaja Kopernika w Toruniu, Katedra Pedagogiki Społecznej Uniwersytetu Opolskiego, Katedra Pedagogiki Społecznej Uniwersytetu Szczecińskiego, Akademia Pomorska w Słupsku, Akademia Pedagogiki Specjalnej im. M. Grzegorzewskiej w Warszawie), a także emerytowani pracownicy naukowi, studenci i absolwenci Katedry Pedagogiki Społecznej UŁ.

Gościem honorowym był profesor Jean-Marie Barbier z Katedry UNESCO Kształcenia i Praktyk Profesjonalnych CNAM w Paryżu, autor książki, wokół której skoncentrowała się dyskusja panelowa ${ }^{2}$ w części pierwszej wydarzenia.

Prorektor UŁ profesor Tomasz Cieślak, witając zgromadzonych, określił tematykę spotkania jako łączącą „tradycję sięgającą początków Uniwersytetu z nowoczesnością". Podkreślił jego międzynarodowy charakter. Dodał, że dyskusja panelowa wokół publikacji zagranicznej oddaje istotę uniwersytetu jako przestrzeni wymiany myśli bez ograniczeń, bez uprzedzeń, bez granic. Gratulował stworzenia „silnego środowiska pedagogów społecznych”, także w kontekście wzbudzania refleksji naukowej dotyczącej aktualnych problemów społecznych.

Dziekan Wydziału Nauk o Wychowaniu UŁ, prof. Danuta Urbaniak-Zając, nawiązała również do początków uczelni i kształcenia w niej pedagogów społecznych. Podkreśliła, że w Łodzi miało ono miejsce zanim powstał uniwersytet. W latach 1928-1939 kształcenie odbywało się w łódzkim oddziale Wolnej Wszechnicy Polskiej. Zwróciła uwagę, że ówczesny Rektor Wszechnicy Warszawskiej Teodor Vieweger planował utworzenie samodzielnej Wszechnicy w Łodzi. Był jednym z organizatorów Uniwersytetu i zaproponował jego nazwę nawiązującą do Wszechnicy. Miała ona brzmieć: Wolna Wszechnica Polska Uniwersytet Państwowy w Łodzi. Vieweger powołał organizatorów trzech wydziałów: humanistycznego, matematyczno-przyrodniczego i pedagogicznego oraz Studium Pracy Kulturalno-Oświatowej, którym (jako czwartym wydziałem) miała kierować prof. Helena Radlińska. Jednak struktura organizacyjna uniwersytetu się zmieniła. Najpierw Studium zostało włączone do wydziału pedagogicznego, a następnie wydział pedagogiczny do wydziału humanistycznego. W 1945 r. powołano Uniwersytet Łódzki i od tego czasu, z przerwą, funkcjonuje w jego ramach - Zakład, potem Katedra Pedagogiki Społecznej. W 1948 r. wstrzymano nabór na filozofię o specjalności: pedagogika społeczna, a w 1952 r. ostatecznie zamknięto Katedrę Pedagogiki Społecznej, którą reaktywowano w roku akad. 1961/1962. Katedrą kierował wówczas profesor Aleksander Kamiński, potem profesor Irena Lepalczyk, następnie profesor Ewa Marynowicz-Hetka, która kieruje nią po dzień dzisiejszy. W $1991 \mathrm{r}$. został wyodrębniony w strukturze uczelni Wydział Nauk o Wychowaniu i w bieżącym roku obchodzi jubileusz 25 lat swojego funkcjonowania.

\footnotetext{
2 Dyskusję tłumaczyła $\mathrm{z}$ jęz. francuskiego na jęz. polski i odwrotnie współpracująca od wielu lat z Katedrą Pedagogiki Społecznej UŁ pani Grażyna Karbowska.
} 
Prowadząca spotkanie Ewa Marynowicz-Hetka dodała, że uszczegółowienie rysu historycznego znajduje się w prezentacji multimedialnej pt. Pedagogika społeczna w Uniwersytecie Łódzkim: trwanie i zmiana $w$ kontekście zerwania i nieciągłości, faz i progów - atrybutów procesu rozwoju pedagogiki społecznej w Polsce, wyodrębnionych $w$ analizie długiego trwania ${ }^{3}$, która towarzyszyła uczestnikom podczas spotkania. Odwołując się do koncepcji Gastona Bachelarda (2002), podkreśliła, że przeszłość powinna, czy też może, nas interesować o tyle, o ile znajduje swoje odzwierciedlenie w teraźniejszości i przyszłości i zaproponowała w dalszej części spotkania dyskusję panelową będącą świadectwem aktualnych inspiracji prac badawczych prowadzonych w Katedrze Pedagogiki Społecznej UŁ.

\section{Dyskusja panelowa wokół książki Jean-Marie Barbiera (2016) pt. Leksykon analizy aktywności. Konceptualizacje zwyczajowych pojęć}

Do udziału w dyskusji panelowej zaproszono ${ }^{4}$ autora książki Jean-Marie Barbiera, recenzentów: Lecha Witkowskiego i Piotra Łukowskiego oraz badaczki podejmujące zagadnienia omawiane w książce: Danutę Urbaniak-Zając i Annę Walczak.

Dyskusja toczyła się wokół trzech głównych obszarów tematycznych:

- transwersalnego podejścia do analizy aktywności, proponowanego w Leksykonie, i jego wymiarów: epistemologicznego, metodologicznego i teoretycznego;

- przydatności tej koncepcji dla badań nad aktywnością i kształceniem;

- innych spostrzeżeń odnoszących się do promowanej książki.

W pierwszej kolejności zabrał głos autor Leksykonu, który określił swoją książkę jako wpisaną w dyskurs antropologii praktyki. W publikacji Barbier rozwija tę myśl - pisze o antropologii praktyk profesjonalnych, która stanowi dyskurs metateoretyczny zawierający strukturę konceptualną mającą badawcze zastosowanie w analizie różnych pól praktyki (Barbier 2016: 16).

Autor Leksykonu rozpoczął swoją wypowiedź od nakreślenia wątków biograficznych odkrywających intencje, powody, które spowodowały, że napisał właśnie taką książkę. Ze względu na to, że w jego środowisku rodzinnym nie było rozgraniczenia pomiędzy życiem rodzinnym a życiem zawodowym, autor nie traktuje pracy w opozycji do nurtu życia. Aktywność, którą człowiek nazywa pracą, jest z jego

\footnotetext{
${ }^{3}$ Opracowana na okoliczność 70-lecia Katedry Pedagogiki Społecznej UŁ (1945-2015) przez E. Marynowicz-Hetkę, E. Skoczylas-Namielską i I. Kamińską-Jatczak.

${ }^{4}$ Jean-Marie Barbier, Katedra UNESCO Kształcenia i Praktyk Profesjonalnych, Conservatoire National des Artrs et Métieres, Paryż; Lech Witkowski, Zakład Pedagogiki Ogólnej i Podstaw Edukacji, Akademia Pomorska w Słupsku; Piotr Łukowski, Zakład Kognitywistyki Instytutu Psychologii UŁ; Danuta Urbaniak-Zając, Zakład Badań Jakościowych Katedry Badań Edukacyjnych UŁ; Anna Walczak, Zakład Pedagogiki Filozoficznej Katedry Teorii Wychowania UŁ. Dyskusję moderowała Ewa Marynowicz-Hetka, Katedra Pedagogiki Społecznej UŁ.
} 
punktu widzenia wpisana w życie stanowiące proces, w którym i dzięki któremu jest ona realizowana (tamże: 258).

Wielodyscyplinarne wykształcenie - filozoficzne, socjologiczne i ekonomiczne oraz doświadczenie praktyczne - praca w instytucjach stricte uniwersyteckich, naukowych, jak Ecole Pratique des Hautes Etudes w Paryżu, a następnie w Consevatoire National des Arts et Métiers w Paryżu, gdzie w badaniach analizuje się różne pola praktyki i kształci się wysoko kwalifikowanych (masters, doktoraty) praktyków, to wszystko sprawiło, że autor skoncentrował się na pojmowalności zwyczajowych ram werbalizacji działania (tamże: 12). Jest to epistemologiczny wymiar Leksykonu, w którym chodzi o to, by naukowo rozpatrywać konceptualizacje zwyczajowych pojęć, czyli formułować znaczenia terminów powszechnie używanych, często tak oczywistych, że pozostających poza refleksją.

Publikacja nie ma charakteru normatywnego, nie chodzi w niej o to, by wskazywać praktykom, co należy czynić. Taka wiedza jest narzucona z zewnątrz i nie ma swojego zastosowania w pojmowalności praktyki. Dzieje się tak, ponieważ zazwyczaj czynimy inaczej niż należy i odmiennie w stosunku do tego, co zamierzaliśmy. Chodzi natomiast o to, by analizować rzeczywistą praktykę - codzienne aktywności, co może zostać spożytkowane dla kształcenia przyszłych kadr profesjonalistów.

Na podstawie udziału w wielu spotkaniach międzynarodowych, gdzie poruszano tematykę działania i praktyki, autor dostrzegł, że używa się tam głównie narzędzi/odniesień kulturowych, a nie naukowych. Badacze z różnych dyscyplin naukowych, pisząc o działaniu, używają kategorii zwyczajowych/potocznych. Zatem te kategorie zwyczajowe są „pasażerami na gapę” dyskursu naukowego. Nie wiemy, że one są w tym dyskursie, ale one tam są.

Autor podzielił się także z zebranymi trudnościami intelektualnymi, jakie napotkał w toku konstruowania zaproponowanej perspektywy 'myślenia o myśleniu o aktywnościach', które przyczyniły się do strukturyzacji jego myślenia.

Po pierwsze, trudność związana z oddzieleniem od siebie dwóch rodzajów dyskursów - opartego o reprezentacje finalizowane (tamże: 195-196) oraz reprezentacje finalizujące (tamże: 196-197). Pierwszy z nich dotyczy tego, co istnieje, co podmioty myślą o sobie, o aktywności i jej otoczeniu. Drugi wyraża to, co podmioty uznają za pożądane, co nadaje sens ich aktywności. Ten typ dyskursu ujawnia afekty podmiotu działającego oraz jego poziom zaangażowania w określoną aktywność. Dyskurs naukowy (finalizowany) miesza się z dyskursem finalizującym.

Po drugie, trudność w odróżnieniu sensu (tamże: 204) i znaczenia (tamże: 255-256). Sens stanowi specyficzną konstrukcję mentalną, którą adresujemy do samych siebie, sens jest konstruowany. Natomiast znaczenie wytwarza się w procesie komunikacji i jest tym, co ja chcę powiedzieć. W Leksykonie znajdują się znaczenia tego, co chce powiedzieć jego autor.

Po trzecie, kwestia zrozumienia, że aktywność to nie tylko to, co widać, gdyż (tamże: 46-47) ma ona również wymiar niewidoczny, mentalny. Praca mentalna jest również aktywnością. Aktywność mentalna podobnie jak inne wymiary aktyw- 
ności jest adresowana do siebie samego i jednocześnie jest procesem transformacji świata oraz transformacji podmiotu, który przekształca świat. W aktywności uczestniczy również percepcja, gdyż podmiot postrzega świat, który przekształca, oraz siebie jako podmiot działający.

Po czwarte, aby wyjść naprzeciw trudności, jaką jest podejście holistyczne/kompleksowe $\mathrm{w}$ analizie aktywności, Barbiera zainteresowały przestrzenie aktywności (tamże: 182-183) - między innymi mentalna i dyskursywna - oraz ich konfiguracje (tamże: 107). Na przykład, podmiot działający podczas komunikacji uruchamia określone reprezentacje, które nie muszą być obecne w jego dyskursie. Aktywność może być charakteryzowana przez pryzmat transformacji powiązanych (tamże: 230-231), co powoduje, że jeśli wpływam na jedną przestrzeń aktywności, to taka zmiana wpływa na dalsze transformacje. Następujące zmiany są ze sobą skorelowane. Według Johna Deweya, kiedy działam, mogę oddziaływać na to, nad czym panuję, ale nie można panować nad wszystkim (por. Dewey 1988: 214). Kiedy wpływam na działania innego, to wpływam również na jego reprezentacje.

W dalszej kolejności zabrali głos paneliści. Danuta Urbaniak-Zając zauważyła, że nie wiemy, jak badać praktykę, gdyż jeśli badamy dyskurs praktyków, to docieramy do ich interpretacji, a nie do tego, co rzeczywiście robią. Dlatego ważne jest, by w badaniu praktyki nie ograniczać się jedynie do przestrzeni dyskursywnej. Pojawia się zatem pytanie dotyczące tego, jak poznać praktykę działania? Na ten problem również zwraca uwagę autor Leksykonu i sugeruje prowadzenie obserwacji równolegle $\mathrm{z}$ analizą wypowiedzi. Jednak badacz zawsze nakłada własną interpretację na to, co obserwuje, a problem nadal pozostaje nierozwiązany. W tym obszarze Leksykon nie udziela odpowiedzi, wciąż nie wiemy, w jaki sposób poznawać praktykę.

Piotr Łukowski zwrócił uwagę na oryginalną strukturę książki, którą charakteryzuje holistyczne podejście do prezentowanych znaczeń oraz konstruktywny charakter definiowania. W Leksykonie występuje definiowanie konstruktywne, częściowo zmieniające znaczenia pojęć, które jest autorskim pomysłem Barbiera. Konstruuje on bowiem własny obraz świata, stanowiący punkt odniesienia dla definiowanych znaczeń. W Leksykonie występuje połączenie definiowania klasycznego $^{5}$ ze swego rodzaju definiowaniem przez postulaty. Pierwsze zdanie każdego hasła, to wskazanie rodzaju definiowanego gatunku. Pozostała jego część dotyczy różnicy gatunkowej - czym definiowany gatunek różni się od pozostałych mieszczących się $\mathrm{w}$ ramach jednego rodzaju. W Leksykonie mamy do czynienia z holistycznym podejściem do przedstawiania znaczeń i definiowaniem przez postulaty, w którym chodzi o to, by wszystkie zdania mieszczące się w obrębie definicji były prawdziwe. Ten rodzaj definiowania jest realizowany poprzez wprowadzanie odmiennych terminów, zdefiniowanych w innych miejscach Leksykonu. Taka struktura wypowiedzi wymaga „podróży po sieci znaczeń”, by zrozumieć definio-

\footnotetext{
${ }^{5}$ Gatunek definiowany przez rodzaj i różnicę gatunkową (Łukowski 2012).
} 
wany termin. „Podróż” może odbywać się w różnych kierunkach i prowadzić do różnych konstatacji, które nie są ze sobą sprzeczne, biorąc pod uwagę punkt widzenia konstrukcji teorii logicznych. Za każdym razem, kiedy wyruszymy w tę podróż, możemy inaczej odczytać dane pojęcie, ale będą to odczytania ze sobą kompatybilne. Piotr Łukowski przywołał zdarzenie opisane w książce Konające zwierze Philipa Rotha (2016) - profesor literatury David Kepesh na swoim wykładzie zadaje studentom pytanie: Czy Wojna i Pokój przeczytana ponownie po latach jest tym samym utworem literackim? Pojawia się odpowiedź: „nie, my się zmieniliśmy i już inaczej ją odczytujemy”. Konstrukcja Leksykonu stymuluje zmieniające się odczytania jego treści. W tym sensie książkę tę można traktować jako „dzieło sztuki”, które dostarcza „innej interpretacji”. Leksykon nie jest przeznaczony do linearnej lektury, ale warto ją zacząć od pewnych terminów „startowych”. Leksykon zaprasza czytelnika do „czytania aktywnego”, w którym ma on do czynienia z siecią znaczeń pojęć zwyczajowych (powstałych na bazie języka naturalnego). Sieć tych znaczeń jest „porwana”, zawiera luki oraz cyrkularne i spiralne powiązania.

Ustosunkowując się do wypowiedzi profesora Łukowskiego, Ewa Marynowicz-Hetka porównała tworzenie Leksykonu do koncepcji zerwań i nieciągłości Gastona Bachelarda (2002). Jest to bowiem nieustający proces pracy, który nie został zakończony z chwilą wydania książki.

Anna Walczak rozpoczęła swoje wystąpienie od nawiązania do książki Martina Heideggera (2000) Co zwie się myśleniem?. W dziele tym przywoływany autor stwierdza, że wszyscy myślimy, posiadamy myśli, ale to jeszcze nie świadczy o tym, że potrafimy myśleć. Żeby móc myśleć, coś musi nam dać do myślenia. Zazwyczaj to, co daje nam do myślenia, staje w opozycji do nas. Jak by to powiedział Paul Ricoeur ([1990] 2003) - jest czymś innym, obcym, co jednak odnajdujemy w nas samych. Obcością w tym Leksykonie jest „zderzenie się z nieoczywistością znaczeń”. W publikacji występuje „odznaczanie pojęć”, które uwrażliwiają na samą aktywność myślenia i skłaniają do namysłu nad wykładnią powszechnie proponowanych znaczeń. W Leksykonie pojawia się propozycja znaczeń nieoczywistych pobudzająca odczucie problematyczności u czytelnika, które uruchamia jego myślenie. Chodzi tutaj również o takiego czytelnika, traktującego Leksykon jako propozycję narzędzia analizy, które będzie próbował zastosować w „terenie”, przez co odkryje problematyczność znaczeń obecnych, do których przywykliśmy. To, co było dotychczas dla nas oczywiste, po lekturze książki może przestać takie być. Leksykon skłania do refleksji 'nad', 'w' i 'o' aktywności/działaniu. Dostarcza narzędzi, które mogą pełnić rolę „drogowskazów analizy” w odkrywaniu „nowego innego”, ponownego konstruowania sensów wykraczających poza dotychczasowe odczytania i interpretacje aktywności/działania. Jeśli jednak potraktujemy Leksykon jako narzędzie poznania, to powstaje pytanie, czy wystarczy samo „przyłożenie” pojęć w nim zawartych do analizowanej rzeczywistości, by uczynić przejrzystymi tkwiące w niej sensy. W odniesieniu do stanowisk hermeneutycznych, fenomenologicznych odpowiedź jest negatywna. Dodatkowo interpretacja aktywności jest zmienna w czasie i nie 
jest tylko własną interpretacją, gdyż jesteśmy zakorzenieni w kontekstach, które rzutują na dobór narzędzi analizy. Anna Walczak na koniec przytoczyła słowa Witkiewicza: „lecz myśl ta czyja? Samo się nie myśli” (1921), wskazując na to, że myśli zawsze mają określonego autora, wpisanego w dany kontekst, czy też „właściciela", jakby to powiedział Ricoeur (por. Ricoeur 1989). W efekcie Leksykon można potraktować jako publikację zawierającą narzędzia analizy aktywności własnej - własnego sposobu myślenia. Lektura książki może być sposobnością do myślenia o sobie samym.

Lech Witkowski zarysował strukturę swojej wypowiedzi wokół pojęć zawartych w tytule publikacji.

Po pierwsze - „leksykon”. Wincenty Okoń (2012), polski mistrz leksykografii, prawdopodobnie nie zdawał sobie sprawy z tego, że podjął wysiłek całożyciowy. Podobnie autor tej książki być może nie zdawał sobie sprawy z tego, że „skazał się” na pracę przez całe życie nad analizą aktywności. Jest to - jak określił Witkowski - „wyzwanie przeklęte, niewdzięczne, heroiczne, wymagające odwagi, każdy kto się na nie porywa, wie, ile ryzykuje". Nieprzypadkowo, zdaniem Witkowskiego, autor dziękował za to, w jakim kształcie ukazał się Leksykon, gdyż dodaje mu to odwagi do dalszej pracy.

Po drugie - „aktywność”. Witkowski stwierdza, że funkcję „identyfikującego horyzontu” dla publikacji pełni użyte w niej sformułowanie, a mianowicie „antropologia praktyki". W polskim dyskursie naukowym nie ma na ten temat podręczników, nie funkcjonują katedry naukowe, które zajmowałyby się taką tematyką. Okoń podkreślał, że rozwój leksykografii w obrębie danej dyscypliny naukowej świadczy o jej żywotności i dojrzałości (Okoń 2007: 5-7). Witkowski nawiązuje do tej myśli i mówi o Leksykonie jako świadectwie „progu przesilenia dojrzałości” myślenia antropologicznego o praktyce. W tym sensie powstanie Leksykonu jest przypadkiem szczególnym. Jest on bowiem emanacją narodzin nowej perspektywy rozumienia, która zakłada, że praktyka wymaga antropologii. Antropologiczne myślenie wymaga z kolei nie tylko zanurzenia praktyki w nurcie badań opisujących, ale również troski o nadawanie praktyce nowych jakości. „Antropologia praktyki” jest bliska twórczości Heleny Radlińskiej i powinna być sprzęgana z „ekologią umysłu” nazwaną tak pod wpływem teorii komunikacji Gregory'ego Batesona (Witkowski 2016). Chodzi tutaj o dwubiegunowe sprzężenie tych perspektyw teoretycznych, które może stanowić ujęcie komplementarne dla dyskutowanej perspektywy myślenia o praktyce.

Po trzecie - pojęcie analizy. Lech Witkowski przywołał za Bachelardem (2002) termin 'matematyzacji' obecny w Posłowiu (Marynowicz-Hetka 2016), który dobrze urzeczywistnia strategię analizy przedstawioną w Leksykonie, polegającą na „czynieniu obcym tego, co bliskie”. Chodzi o to, by właściwie rozumieć termin „analiza” zamieszczony w książce, zgodnie z przesłankami 'matematyzacji'. Na co dzień działamy wbrew 'matematyzacji', staramy się uczynić bliskim to, co jest dziw- 
ne/obce i jednocześnie tylko nam się wydaje, że udało się nam to osiągnąć. Realność, na przykład, dotycząca drugiego człowieka, któremu chcemy pomóc, jest nie tylko nieprzejrzysta, ale również opiera się wysiłkowi uczynienia jej bliską. Należy zatem poszukiwać perspektywy, która z jednej strony poruszy, a z drugiej nie będzie trywialną odpowiedniością prawdy. Chodzi o postulowanie prawdziwości ontologicznej, jaka wyłania się z książki. Taki postulat dotyczy intencji tego, by coś naprawdę się stało, byśmy naprawdę dotarli do odbiorcy, który może nie być gotowy nas wysłuchać, który może być na granicy odruchów samobójczych, któremu nie jest łatwo być sobą, blisko siebie, który nie ułatwia zbliżenia. W tym wypadku uczynienie obcym tego, co bliskie, oznacza wykonanie pracy antropologicznej rzutującej na prawdziwość naszej praktyki. Jest ona związana z tym, że nie można do końca zaprogramować tego, co się stanie, nasze intencje i język mogą nie być podzielane, spotkanie może, a nawet musi być wstrząsem.

Zdaniem Witkowskiego, lektura Leksykonu może stać się wydarzeniem, które przerywa bieg aktywności, narusza dotychczasowe wyobrażenia, ład. Chodzi zatem o paradoksalne postulaty prawdy ontologicznej, które są jednocześnie wymaganiami o charakterze aksjologicznym. Nie chodzi tu o roszczenia normatywne, gdzie nauczyciel powie uczniowi, co ma myśleć, a pracownik socjalny powie człowiekowi, jak ma żyć. Tym bardziej, że w podejmowaniu aktywności adresowanej ważnym terminem jest „opór”. W praktyce, praca z oporem staje się kluczowa, dlatego należy go włączyć w strategię aktywności. Nie jest on tylko uporem. Na praktykę edukacyjną należy spojrzeć jako na aktywność przekształcania, zgodnie ze znaczeniem greckiego słowa Paideia, które oznacza proces przekształcania, a nie jedynie wykształcenie. Nauczyciele są często niezdolni do aktywności w tym sensie. Można spędzić wiele godzin na wykładach, które nic nie dają i nikogo nie przekształcają, nie dają do myślenia i nie uruchamiają tego, co W. Okoń nazywał „dydaktyką przeżycia”, co można nazwać za antropologią inicjacji „wymogiem przebudzenia”. Przeżycie, przebudzenie i przemiana są tymi elementami strategii aktywności, nad którymi nie panujemy. Możemy jedynie uruchomić ten proces, który jest wykorzystywany w sytuacji, gdy naprawdę coś się stało. Warto zadać pytanie - czy w aktach działania jesteśmy zawsze obecni? Można przywołać myśl Jacques’a Maritaina, który twierdził, że warunkiem obecności jest gotowość do zaangażowania w spotkanie. Wymagania normatywne często wymykają się naszej kontroli i nie jesteśmy w stanie spowodować, by coś się stało naprawdę.

Reasumując, terminy: 'leksykon', 'analiza', 'aktywność' zwiastują szansę, że wraz z myśleniem o naszej aktywności/działaniu doświadczamy wydarzenia przerywającego poczucie zadomowienia w praktyce, w której rzekomo nic złego się nie dzieje. Wydarzenie dzieła wymaga dostępu do pytań rzadko zadawanych i do wątpliwości, których się nie widzi.

Leksykon zwraca uwagę na kryzys dotychczasowego podziału pól badawczych, dydaktycznych. Antropologia praktyki postuluje analizę, która nie jest tradycyjnym myśleniem analitycznym, ale dotyczy prawdy ontologicznej. Można to sparafrazo- 
wać słowami - „, ja nie muszę cię przekonać, ale muszę znaleźć sposób, byś ty coś zrobił z tym, co ja ci daję”. Chodzi zatem o to, by pozyskać człowieka do tego, „by coś ze sobą uczynił". W typowej sytuacji edukacyjnej ludzie nie są skorzy do przekształcania, uruchamiają opór. Pracownik socjalny może adresować swoją aktywność do kogoś, kto nie jest na to gotów. Zatem, zobaczenie obcości w „zadomowionej praktyce" stanowi sposobność odkrycia nowej jakości.

Wypowiedzi panelistów pobudziły pozostałych uczestników do różnych odniesień, związanych m.in. z rozumieniem pojęcia aktywności. Iwona Janicka ${ }^{6}$ podkreśliła, że spotkanie jest dla niej rzeczywiście wydarzeniem, ponieważ przerywa jej ład i porządek rozumienia pojęcia aktywności. W swojej wypowiedzi, odwołując się do koncepcji Tadeusza Tomaszewskiego i Józefa Kozieleckiego, przypomniała, w jaki sposób psychologowie rozumieją aktywność - inny od propozycji zawartej w Leksykonie.

Alina Wróbel ${ }^{7}$ odniosła się do podtytułu, w którym formalnie nie występuje kategoria antropologii praktyki. Jednak jeśli przyjąć, że pedagogika jest nauką, której przedmiotem badań jest szeroko rozumiana edukacja, pojmowana jako praktyka społeczno-kulturowa, to odniesienie się do antropologicznych podstaw aktywności czy też antropologicznych podstaw działania jest ważne i pozostaje w określonej zależności z istotą, specyfiką, właściwościami działania/aktywności. Szczególne znaczenie ma procesualność aktywności/działania w relacji między teorią a praktyką pedagogiczną, czyli między myśleniem, rozumieniem a działaniem. Alina Wróbel zwróciła również uwagę na rozumienie poszczególnych pojęć, kategorii pojęciowych, które zamieszczone są Leksykonie, na różnicę w sposobie definiowania aktywności i działania, na ich zakresy pojęciowe. Włączając się w dyskusję, Ewa Marynowicz-Hetka zasygnalizowała, że wtedy, kiedy myślimy o analizie praktyki, ważne jest odróżnienie (Barbier 2016: 205-209) słownictwa działania i słownictwa pojmowalności działania.

W kontekście informacji, że Leksykon będzie tłumaczony na język portugalski i hiszpański Eleonora Bielawska-Batorowicz ${ }^{8}$ sformułowała pytanie o uniwersalność koncepcji analizy i samego Leksykonu - pojęć w nim zawartych, zwłaszcza, że jak powiedziała, działanie, szczególnie profesjonalne, jest bardzo uwarunkowane kontekstowo, kontekstem społecznym i kulturowym.

Lech Witkowski, nawiązując do wspomnianego przez Iwonę Janicką podziału aktywności na zewnętrzną i wewnętrzną, zapewnił, że nie ma „pęknięcia” między przywołanymi stanowiskami psychologicznymi i tym, co jest w książce. Stwierdził, że psychoanaliza (Lacana) w wyrafinowanej wersji jest obecna i że do tej perspektywy antropologicznej mniej się przyda myślenie w kategoriach samowiedzy, obecne u Kozieleckiego. Należy raczej postawić pytanie o to, jaka teoria psychologiczna, psychologia głębi czy Gestalt, da się łatwiej „oswoić”, zintegrować z antropo-

\footnotetext{
${ }^{6}$ Zakład Psychologii Społecznej i Badań nad Rodziną, Instytut Psychologii, Wydział Nauk o Wychowaniu UŁ. ${ }^{7}$ Zakład Teorii Kształcenia i Wychowania, Katedra Teorii Wychowania, Wydział Nauk o Wychowaniu UŁ. 8 Zakład Psychopatologii i Psychologii Klinicznej, Instytut Psychologii UŁ.
} 
logią praktyki. Zdaniem Witkowskiego stanowisko Kozieleckiego (1981) związane z psychologią opartą na paradygmacie samowiedzy niezbyt przystaje do perspektywy antropologicznej.

Lech Witkowski odniósł się również do kwestii uniwersalności. Stwierdził, że metodologicznie jest ona dość łatwa do pokazania, jeśli przezwyciężymy w sobie oczekiwanie na poziomie komunikacji i narracji kulturowej, gdzie tej uniwersalności nie ma. Jednak tak rozumiana uniwersalność nie jest potrzebna, ponieważ jest to uniwersalność metanarracyjna. Odniósł się do przykładu pracownika socjalnego, nauczyciela, który spotyka się z różnymi sposobami oporu, pokazując uniwersalność tej kategorii. Natomiast sposoby przejawiania oporu są kulturowo zróżnicowane. Witkowski, odwołując się do obecnych w Leksykonie tropów Lacanowskich podkreślających związek między tym, co realne a tym, co wyobrażeniowe i tym, co symboliczne, przywołał też inne przykłady ilustrujące różnicowanie się tego mechanizmu uniwersalności. Wskazał m.in. na błędy i fikcyjność terapii. Przykładem mogą być ludzie, którzy wychodzą z więzienia po wielu nieudanych terapiach, czy też sytuacje, w których terapeuta próbuje tłumaczyć pacjentowi, na podstawie podręcznika, przebieg jego życia, tymczasem pacjent chce, aby terapeuta, wykorzystując jego doświadczenie, zastanowił się nad samym sobą. W innej sytuacji niepełnosprawne matka i córka były zachęcane przez psychologa do rezygnacji z podejmowania dalszego wysiłku kształcenia. Uniwersalne jest zachęcanie do wysiłku, natomiast sposób, w jaki się to czyni, jest warunkowany kontekstem kulturowym, społecznym. W Leksykonie Barbier pokazuje, że typowe działania, jak np. kształcenie, często nie są przekształcające, są fikcją, pozorem, pozorowaniem realności oddziaływania, fikcją pomocy z udziałem pracownika socjalnego. Tak pojmowane znaczenie uniwersalności jest ważne dla rozumianej w ten sposób antropologii praktyki.

Piotr Łukowski, odnosząc się do pytania o uniwersalność Leksykonu, powiedział, że także je sobie postawił, kiedy dowiedział się o zamiarze przełożenia go na język portugalski i hiszpański. Tym bardziej, że miał świadomość nakładu czasu dla jego przekładu oraz świadomość tego, że jako logik musiał rozpoznać nietypowość konstrukcji książki, której lektura stanowiła dla niego wyzwanie intelektualne. Dokonując tłumaczenia Leksykonu, bardzo łatwo zrobić z niego zwykły słownik, taki, w którym nie będzie żadnego podążania po sieci znaczeń, rekonstrukcji, która jest naprawdę interesująca. Odnosząc się do postulatywności (choć w innym znaczeniu niż użył go Lech Witkowski), powiedział, że postulatywność definiowania oznacza, że kiedy czytelnik jeszcze nie rozpoznał znaczenia innych terminów zawartych w Leksykonie - to żeby rekonstruować prawdziwość obrazu, zaproponowanego przez autora, stara się rozumieć terminy, podążając $\mathrm{w}$ rozpoznawaniu znaczeń po ich sieci, a nie po kolei. Zdaniem Piotra Łukowskiego, tego typu słownik mógł powstać tylko wtedy, kiedy jest jeden autor.

Olga Czerniawska, zabierając głos, zwróciła uwagę, że w gerontologii coraz częściej stawiane jest pytanie, czy wycofywanie się osób starszych jest aktywnością, 
czy też jej brakiem. Odwołując się do wypowiedzi panelistów, stwierdziła, że może być aktywnością, mimo że jej zewnętrzne objawy nie są obserwowane, ale przecież dopóki człowiek żyje, to myśli, a więc jest to aktywność przekształcająca osobowość, choć, jak powiedział Lech Witkowski, czasem aktywność, jaką jest nauczanie, nie jest aktywnością odwzajemnioną, wiedza przepływa i nie przekształca jednostki.

Zbliżając się do konkluzji dyskusji, ponownie zabrali głos paneliści. Odwołując się do podjętego w niektórych wypowiedziach problemu antropologii praktyki, Lech Witkowski stwierdził, że postulat antropologii praktyki jest zgodny z jego odczytaniem uniwersalnego charakteru pedagogiki społecznej w tym sensie, że pedagogika społeczna niesie przesłania dla wszystkich pedagogów. Bohdan Suchodolski (1980) mówił, że nie można uprawiać pedagogiki ogólnej, nie wykorzystując inspiracji z pedagogiki społecznej. Zdaniem Witkowskiego antropologia praktyki jest wpisana „w poprzek”, transwersalnie, w strategię i kulturę umysłową. Termin „transwersalność" bywa jeszcze ciągle traktowany jako wątpliwy, nieczytelny, a przecież pokazuje on, że „rozumności nie da się zamknąć w żadnej jednej, wąskiej, zaszufladkowanej racjonalności metodycznej, czy intencjonalnej, czy też związanej z wizją dobra, które chcemy czynić drugiemu człowiekowi”. Dodał, że transwersalność oznacza „zobowiązanie bycia w poprzek”, a profesor J.-M. Barbier jest transwersalnym humanistą, dlatego mógł się odważyć, by podjąć ryzyko napisania słownika, który będzie uzupełniał, poprawiał, przekształcał...

W kontekście powrotu do lektury Leksykonu, Anna Walczak, odwołując się do Gabriela Marcela, przytoczyła metaforę: lektura ma wtedy sens, kiedy uczy nas stawać się stopniowo bezdomnym, w kierunku podążania ku zadomowianiu się, nowemu, innemu. Jej zdaniem taką wartość ma właśnie Leksykon.

Odnosząc się do wypowiedzi o uniwersalność omawianej koncepcji, Danuta Urbaniak-Zając stwierdziła, że są one zgodne z jej myśleniem z punktu widzenia propozycji formalnego ujęcia analizy aktywności człowieka, które rozumie jako ujęcie uniwersalne. Zgadza się z Lechem Witkowskim, że „szatkowanie praktyki działania jest szatkowaniem człowieka" na dyscypliny, jest ograniczeniem, ale tak funkcjonuje nauka i dopiero na najwyższym poziomie ogólności można próbować formułować uogólnienia. Jeśli za każdym razem rekonstruowano by antropologię praktyki 'na własny użytek', to prawdopodobnie byłaby adekwatna dla danego działania. Bardzo ważne są warunki, okoliczności, w jakich działanie przebiega, od których zależy. Należy je rozumieć w sposób strukturalny, czego nie dostrzega się w koncepcji omawianej książki. Z punktu widzenia własnych zainteresowań badawczych (Urbaniak-Zając 2016), w których podejmuje zagadnienia profesjonalizacji, m.in. w ujęciu niemieckiego dyskursu naukowego, dostrzega w omawianej koncepcji pewne luki, odnoszące się do analizy uwarunkowań strukturalnych przebiegu działań podejmowanych przez praktyków. Recepcja Leksykonu z takiej perspektywy może wywoływać pewien rodzaj oporu. 
Lech Witkowski podkreślił dyskomfort sytuacji związany z niemożnością wnikliwego przestudiowania Leksykonu i że z tego wynikają prawdopodobnie niektóre pytania, trudności. Nawet w pierwszym odbiorze książka Barbiera nie reprezentuje sentymentalnego humanizmu. Zwykle w praktyce opieramy się na pierwszym wrażeniu. Tymczasem antropologia praktyki „traktowana na serio” powinna postulować zdolność, by opierać się pierwszemu wrażeniu, bowiem bywa ono źródłem decyzji, rozstrzygnięć, ocen lekarzy, nauczycieli, polityków, psychoterapeutów itd. Postulaty i oczekiwania, które zostały sformułowane podczas dyskusji, znajdują, jego zdaniem, odzwierciedlenie w książce. Chodzi również o kwestie poszukiwania oporu, przejrzystości, narracji inaczej strukturyzującej pole dyskursu. Warto poddawać refleksji treści zawarte w tym Leksykonie, bo inaczej nie będzie zdarzenia, nie będzie spotkania, efektu, który mógłby nas przekształcić. Na początku jego lektury być może niektórzy czytelnicy przeżyją pewien dyskomfort, ale i pouczający wstrząs, który w polemice z Jean-Marie Barbierem pomoże dalej budować aspekty komplementarne, wzbogacające zaproponowaną przez niego perspektywę. W tym kontekście trafne jest, zdaniem Marynowicz-Hetki, określenie, że ta książka: „jest podróżą po sieci znaczeń”.

Piotr Łukowski podkreślił, że w niektórych wypowiedziach, może błędnie, przebija postulat uniwersalności promowanej książki, podczas gdy on postrzegał ją nie jako uniwersalną, ale jako autorską. Napotykał podczas lektury na problemy logiczne, jak np.: czy przerwanie działania jest działaniem, jak zdefiniować profesjonalistę? Odczytuje ją jako projekt autorski czytany po to, by zobaczyć coś nowego, aby za radami, sugestiami autora móc konstruować własny świat.

Na zakończenie dyskusji zabrał głos Autor, rozpoczynając wypowiedź od odniesienia do trafnej - jego zdaniem - metafory Marcela, iż bycie zmuszonym do myślenia oznacza bycie bezdomnym w aktywności myślenia, która bardzo mu się podoba i odpowiada jego projektowi. Zwrócił uwagę na to, że kiedy mamy bardzo dużo aktywności, musimy wyodrębnić różne jej przestrzenie. Obejmuje to samą przestrzeń tej aktywności, na temat której mamy wytworzyć pewną wiedzę, przestrzeń transformacji reprezentacji jednostki o jej własnej aktywności, jak i przestrzeń werbalizacji aktywności i wszystkie aktywności mentalne, zarówno analizy, jak i interpretacji, której dokonuje sam podmiot działający bądź badacze. Dodał, że nie możemy w sposób jednoznaczny rozwiązać tego problemu. W pracy badawczej w prosty sposób trzeba określić, kto badał, analizował, jakimi narzędziami. W Leksykonie nie ma narzędzi, żeby rozwiązać ten problem. Musi być pewna transparentność w tej dziedzinie badań.

Autor wyraźnie podkreślił, że Leksykon nie jest słownikiem aktywności. Nie proponuje narzędzi do myślenia o aktywnościach, gdyby tak było, to propozycja byłaby nie tyle uniwersalna, co wręcz 'terrorystyczna'. Leksykon proponuje narzędzia do myślenia o myśleniu na temat aktywności. Proponuje własne interpretacje definicji społecznych. Istnieje więc sfera osobista, ale ma ona służyć interpretacji sfery społecznej. Oczywiście można dyskutować o zaprezentowanej w Leksykonie 
koncepcji, jak o każdej interpretacji osobistej. Autor przyznał, że dzięki uczestnictwu w tym panelu zdał sobie sprawę z konieczności wyodrębnienia dwu znaczeń pojęcia „antropologii”: antropologii działań profesjonalnych i antropologii myślenia i werbalizacji działania. W tej pierwszej przestrzeni wszyscy mogą uczestniczyć, o ile będą zmuszeni do myślenia o swojej aktywności. Intencją Leksykonu jest odwołanie do drugiego znaczenia tego pojęcia, antropologii myślenia i werbalizacji działania. Podkreślił, że być może na poziomie znaczenia słów „antropologia” może stanowić pewne pole do nieporozumień. Cały czas bowiem poruszamy się w sferze społecznej, a nie tylko w wyabstrahowanej naukowej dziedzinie, np. tak jak matematycy. Chciałby włączyć kontekst matematyczny do Leksykonu - matematykę nie jako naukę, ale jako aktywność. Matematyk nie odsyła nas do jakiejś bezpośredniej rzeczywistości, czyli bezwzględnie nie można mówić o uniwersalnych narzędziach. To, co jest uniwersalne to presja, zmuszenie do myślenia i to, w jaki sposób organizujemy to zmuszanie. Może istnieć uniwersalny projekt, który wpisuje się w semantykę różnych światów poszczególnych nauk. W tradycyjnej myśli chińskiej w sposób naturalny myśli się o zmianach i o transformacjach. Natomiast w zachodniej myśli bardziej mówi się o etapach. W badaniach autora przedmiotem badania są narzędzia, które służą nam do podejmowania aktywności, a więc osobista interpretacja definicji społecznych.

Jean-Marie Barbier podziękował za propozycję kontynuowania wspólnej pracy nad Leksykonem, która wymaga dalszego namysłu. Poprosił także, aby rekomendując Leksykon studentom, uwrażliwić ich na zapoznawanie się z wybranymi hasłami, a nie czytanie od pierwszej do ostatniej strony, co może być jedynie przydatne w odniesieniu do Przedmowy i Posłowia. Reagując na tę prośbę, E. Marynowicz-Hetka przypomniała, że jedną z propozycji lektury książki zawarła w Posłowiu.

\section{Podsumowanie dyskusji}

Kończąc debatę i wyrażając nadzieję, że spotkanie było inspirujące, profesor E. Marynowicz-Hetka podziękowała profesorowi J.-M. Barbier, panelistom za lekturę książki i wypowiedzi oraz wszystkim uczestnikom za obecność i aktywność. Przypomniała, że współpracuje z Zespołem Profesora ponad 15 lat - Zespołem Centrum Badań nad Kształceniem, który J.-M. Barbier założył i prowadził przez wiele lat, oraz obecnie prowadzoną Katedrą UNESCO, Kształcenia i Praktyk Profesjonalnych, w których to aktywnościach badawczych znalazła inspiracje dla konstruowania narzędzi epistemologicznych pozwalających na zrozumienie praktyki. Dla pedagogiki społecznej pojęcie działania stanowi podstawową kategorię naukowej refleksji, zaś kategoria praktyki Praxis tego, co się dzieje w jej polu, jest przedmiotem stałej, permanentnej pracy koncepcyjnej, której ślady znajdują swoje odzwierciedlenie w ujęciu pedagogiki społecznej, w dużym stopniu wyłożonej w podręczniku (Marynowicz-Hetka 2006), ale też w innych tekstach. 
Zastanawiając się nad swoją pracą tłumacza i Grażyny Karbowskiej, która, jak określiła E. Marynowicz-Hetka w Posłowiu, trzymała ją w reżimie języka francuskiego, starała się myśleć zgodnie z intencją autora i oddać jego punkt widzenia - indywidualny, osobisty. W odniesieniu do tego, co autor nazywa definicjami społecznymi, intencja tłumaczki była taka, żeby umieścić myśl w kontekście polskim. Stąd poza tekstem autora w Leksykonie jest ponad 100 odniesień do literatury, aby uczynić pracę bardziej przyjazną dla czytelnika polskiego.

Przybliżając walory książki i zachęcając do jej lektury, Ewa Marynowicz-Hetka złożyła na ręce redaktora inicjującego wydanie Leksykonu - wicedyrektor Urszuli Dzieciątkowskiej, podziękowanie Wydawnictwu Uniwersytetu Łódzkiego za wydanie pracy i starania o jej jak najlepszy poziom edytorski.

Z okazji 70-lecia Katedry Pedagogiki Społecznej Uniwersytetu Łódzkiego na ręce jej kierownika profesor Józefa Brągiel złożyła serdeczne gratulacje od Zespołu Katedry Pedagogiki Społecznej Uniwersytetu Opolskiego, podkreślając nieustanną dbałość o pamięć mistrzów i tych wszystkich, którzy tworzyli podstawy pedagogiki społecznej w Uniwersytecie Łódzkim. W ten naturalny sposób uczestnicy spotkania zostali wprowadzeni w jego następny punkt programu, jakim był wernisaż wystawy poświęconej 70-letniemu dorobkowi Katedry Pedagogiki Społecznej w Uniwersytecie Łódzkim.

\section{Bibliografia}

Bachelard G. (2002) Kształtowanie się umysłu naukowego. Przyczynek do psychoanalizy wiedzy obiektywnej, tłum. D. Leszczyński, Gdańsk, Słowo/obraz/terytoria.

Barbier J.-M. (2016) Leksykon analizy aktywności. Konceptualizacje zwyczajowych pojęć, przeł. i oprac. E. Marynowicz-Hetka, Łódź, Wydawnictwo Uniwersytetu Łódzkiego.

Dewey J. (1988) Jak myślimy, tłum. Z. Bastgenówna, Warszawa, PWN.

Heidegger M. (2000) Co zwie się myśleniem?, tłum. J. Mizera, Warszawa, Wydawnictwo Naukowe PWN.

Kozielecki J. (1981) Psychologiczna teoria samowiedzy, Warszawa, PWN.

Łukowski P. (2012) Logika praktyczna z elementami wiedzy o manipulacji, Warszawa, Wydawnictwo Wolters Kluwer SA.

Marynowicz-Hetka E. (2006) Pedagogika społeczna. Podręcznik akademicki, Warszawa, Wydawnictwo Naukowe PWN.

Marynowicz-Hetka E. (2016) Posłowie: Konceptualizacje zwyczajowych ram myślenia o aktywności - na marginesie pracy nad tekstem w: J.-M. Barbier (2016) Leksykon 
analizy aktywności. Konceptualizacje zwyczajowych pojęć, przeł. i oprac. E. Marynowicz-Hetka, Łódź, Wydawnictwo Uniwersytetu Łódzkiego, s. 271-289.

Okoń W. (2007) Nowy słownik pedagogiczny, Warszawa, Wydawnictwo Akademickie „Żak".

Ricoeur P. (1989) Język jako dyskurs, tłum. K. Rosner w: Ricoeur P., Język, tekst, interpretacja: wybór pism, tłum. P. Graff, K. Rosner, wybór i wstęp K. Rosner, Warszawa, Państwowy Instytut Wydawniczy, s. 65-95.

Ricoeur P. ([1990] 2003) O sobie samym jako innym, przeł. B. Chełstowski, Warszawa, Wydawnictwo Naukowe PWN.

Roth P. (2016) Konające zwierzę, tłum. J. Kozak, Kraków, Wydawnictwo Literackie.

Suchodolski B. (1980) Heleny Radlińskiej koncepcja wychowania jako poszukiwania sit i pomocy w rozwoju, „Człowiek w Pracy i w Osiedlu”, nr 2/92/XIX, 3/93/XIX, numer tematyczny Pedagogika społeczna Heleny Radlińskiej, I. Lepalczyk, J. Badura (red.), s. 35-40.

Urbaniak-Zając D. (2016) W poszukiwaniu teorii działania profesjonalnego pedagogów. Badania rekonstrukcyjne, Kraków, Oficyna Wydawnicza „Impuls”.

Witkiewicz S. I. (1921) Tumor mózgowicz. Dramat w 3 aktach z prologiem, Kraków, Spółka Wydawnicza „Fala” sp. z o.o.

Witkowski L. (2016) Konteksty i elementy ekologii umysłu, idei i wychowania według Gregory'ego Batesona w: Humanistyczne wyzwania ekologii umysłu: Gregory Bateson w Polsce, M. Jaworska-Witkowska, L. Witkowski (red.), Warszawa, Fundacja na rzecz Myślenia im. Barbary Skargi.

Izabela Kamińska-Jatczak, Elżbieta Skoczylas-Namielska

\section{Pédagogie Sociale à l'Université de Lodz : le passé \\ - le présent - le futur : la clôture des célébrations du 70 anniversaire de la Chaire de Pédagogie Sociale à l'Université de Lodz}

Le 5 octobre 2016 au Palais Biedermann - siège du musée de l'Université de Lodz - nous avons assisté à l'événement clôturant l'année consacrée à la célébration du 70 anniversaire de l'Université de Lodz et de la Chaire de Pédagogie Sociale. Cet événement intitulé Pédagogie Sociale au sein de 
l'Université de Lodz : le passé - le présent - le futur comprenait deux parties : le panel et l'exposition présentant histoire de la pédagogie sociale au sein de l'Université de Lodz, préparé par les Archives et le Musée de l'UL, en collaboration avec la Chaire de Pédagogie Sociale de l'UL. L'exposition a été inaugurée par l'allocution de Monsieur Dariusz Klemantowicz - directeur des Archives et du Musée de l'UL. L'exposition se composait des photographies et des documents inédits et historiques liés aux grands personnages faisant partie du milieu des pédagogues sociaux de Lodz.

Le panel se déroulait autour de l'édition polonaise du livre de Jean-Marie Barbier Vocabulaire d'analyse des activités. Penser les conceptualisations ordinaires, 2ème édition, Paris, Presses Universitaires France [Leksykon analizy aktywności. Konceptualizacje zwyczajowych pojęć, Łódź 2016, Presses de l'Université de Lodz] sur les questions suivantes :

- l'approche transversale à l'analyse des activités, proposée dans le livre et de ses dimensions: épistémologique, méthodologique et théorique ;

- l'utilité de la conception aux recherches sur l'activité et la formation ;

- d'autres remarques au livre promu.

Les participants du panel : auteur du livre ${ }^{1}$, critiques Lech Witkowski et Piotr Łukowski ainsi que les chercheurs s'intéressant à la problématique de ce livre - Danuta Urbaniak Zając et Anna Walczak.

Jean-Marie Barbier a témoigné des difficultés intellectuelles rencontrées lors de la construction de la perspective de 'penser la pensée sur les activités' qui a structuré sa pensée. Il a attiré l'attention du public sur la difficulté majeure liée à la séparation de deux discours - finalisant, se rapportant à ce qui existe, ce que les sujets pensent sur eux-mêmes, sur l'activité et son environnement (Barbier 2016 : 195-196)² et finalisée - exprimant ce que les sujets considèrent comme souhaitable et ce qui donne le sens à leur activité (ibidem : 196-197). Jean-Marie Barbier a attiré l'attention sur la difficulté de discerner le sens (ibidem : 204), construit à notre intention, de la signification construite dans le processus de communication (ibidem : 255-256). Il a souligné que l'activité possède également une dimension invisible, mentale (ibidem : 46-47) que l'on peut caractériser à travers les transformations liées (ibidem : 230-231).

Danuta Urbaniak Zając a soulevé la question des limites dans les recherches sur la pratique en remarquant que de fait nous ne savons pas

\footnotetext{
1 Jean-Marie Barbier, Chaire de Formation et pratiques professionnelles auprès de l'UNESCO, Conservatoire National des Artrs et Métieres, Paris ; Lech Witkowski, Unité de Pédagogie Générale et d’Education, Académie de Słupsk ; Piotr Łukowski, Unité de Cognitivisme Institut de Psychologie UL ; Danuta Urbaniak-Zając, Unité de Recherches Qualitatives de la Chaire des Recherches Educatives UL; Anna Walczak, Unité de Pédagogie philosophique, Chaire de la Théorie d'Education UL. Modérateur Ewa Marynowicz-Hetka, Chaire de Pédagogie Sociale UL.

${ }^{2}$ Le références bibliografiques voir : l'article à ce sujet dans ce numéro.
} 
comment l'étudier. En faisant la recherche sur le discours des praticiens, nous n'analysons que leurs interprétations au lieu d'étudier ce qu'ils font réellement.

Piotr Łukowski a mis accent sur la structure originale du livre se caractérisant par l'approche holiste des significations présentées, ainsi que le caractère constructif des définitions. Dans son opinion, l'auteur présente sa propre et unique façon de construire les définitions consistant en changement partiel des notions définies et en introduisant dans ces mêmes définitions des termes déjà définies dans d'autres parties du livre. Ainsi la compréhension des catégories définies exige 'un voyage à travers un réseau de significations' qui pourtant mène bien aux constatations cohérentes.

Anna Walczak a partagé son opinion portant sur la proposition des significations non évidentes du Vocabulaire... qui de ce fait invite à penser l'activité. Selon elle, le livre peut être compris en tant que proposition d'un outil d'analyse 'sur', 'dans', et 'à propos' de l'activité. Le livre est utile également pour analyser sa propre activité - sa propre façon de penser.

Lech Witkowski a trouvé que l' 'horizon identifiant' dans ce livre remplit pleinement la formulation employé par l'auteur, notamment celle d'anthropologie de la pratique', qui évoque le besoin de penser de façon anthropologique dans la réflexion sur la pratique. Dans son opinion, cette façon de penser demande une perspective analytique qui se traduit par la notion utilisée dans le poste face du livre (Marynowicz-Hetka 2016), celle de 'mathématisation' (Bachelard 2002), où l'on trouve l'idée de 'rendre étranger ce qui est proche'.

Ewa Marynowicz-Hetka, en récapitulant la discussion du panel, a souligné également que, du point de vue de la pédagogie sociale, la notion d'activité est un concept de base pour la réflexion scientifique, et la pratique 'Praxis', donc ce qui se passe dans ce champ, fait l'objet du travail conceptuel constant dont les traces apparaissent largement dans le livre consacré à la pédagogie sociale (Marynowicz-Hetka 2006), ainsi que dans d'autres textes à ce sujet.

Traduction : Grażyna Karbowska 